\title{
Ordoliberal theory and gas market in Germany within the framework of international energy cooperation
}

\author{
Elena I Piskun ${ }^{1}$, Valeriy Y Chaikin ${ }^{2}$, and Nikita A Nikitin ${ }^{2}$ \\ ${ }^{1}$ Doctor of economic Sciences, chair professor «Finance and Credit», the Sevastopol state university, Sevastopol \\ ${ }^{2}$ Financial University under the Government of the Russian Federation, Moscow
}

\begin{abstract}
German economic policy is a special model of a coordinated market economy, which is based on the tradition of ordoliberalism. This theoretical concept is at the core of the regulation of most economic processes in Germany, and its energy markets are no exception. The article analyses the present state of German gas industry, its transformation in connection with the introduction of the Third Energy Package, the liberalization and development of gas projects. The authors compare the main results of the reforms and the stipulations of the ordoliberal theory. The conclusion is that the German government generally upholds this concept, although sometimes the consequences are of negative nature, manifested in rising prices, added complexity of international natural gas trade, especially with the largest supplier - the Russian Federation. Using the Bertrand competition model, the article justifies the conditions under which the export of liquefied natural gas is beneficial for the Russian Federation.
\end{abstract}

\section{Introduction}

International energy cooperation historically has been a priority for the Russian Federation. Being focused on energy export, Russia remains the strongest player on the European gas market. Germany remains its largest partner. According to Gazprom, gas supplies in this direction amounted to 53.4 billion cubic meters in 2017 alone.

However, changes in pricing model and the liberalization of energy markets are becoming a challenge to Russia's energy policy in Germany. Moreover, competition from the renewable energy and LNG projects of the USA and Qatar is increasing. The questions of how this will affect the structure of international natural gas trade and international energy cooperation in the German market are live and controversial.

As a rule, empirical data, on the basis of which conclusions are drawn, are used to prove any given position. In this research, the authors set a mission of clarifying how the economic principles of ordoliberalism in a coordinated market economy influence the regulation of the natural gas market. Such an approach will allow to outline the trajectory of development of economic and energy policy Germany upholds in changing market conditions, as well as to identify the basic and invariable principles of organization of economic activities in Germany, which Russia should take into account when constructing an energy dialogue. Finally, comparison of current policy and original sources of German liberal thought may provide answers to questions whether German energy policy is organized in accordance with these principles and how it should be implemented.

\section{Ordoliberal theory and economic order}

The core of modern German economic system, which modern researchers call a regulated market economy, is the ordoliberal theory developed in the 1930s and embodied in the market reforms of post-war Germany [1]. Its designers, Walter Eucken, Franz Böhm and Großmann-Doerth formulated through ordoliberal manifesto a doctrine, which combined the classical market liberalism of the classical school and the external controlling subject, creating and organizing a special order, or "rules of the game" [2]. The rule of law and the state that guarantees its observance had a special role. In general, one can distinguish three basic principles of the ordoliberal approach - the competitive order, the market pricing model and government regulation.

The first basis of a coordinated market economy is the advantage of competition over other forms of organization of a state's economic life. W. Eucken have proven in his Die Grundlagen der Nationalökonomie (Principles of National Economy), that competitive order is more efficient, since it motivates an entrepreneur to increase profits by increasing sales, achieved through the introduction of technological and organizational innovations, while the monopoly achieves it by increasing prices [3]. At the same time, one should understand that competition should be carried out at its essential level, without being only a quantitative imitation. The priority is not the number of market

\footnotetext{
* Corresponding author: lenapiskun@mail.ru
} 
participants, but the issue of coordinating their individual economic plans, excluding any possibility of a cartel or a monopoly formation.

Thus, the price formed in a competitive market is an effective tool. The pricing model reveals disproportion in the economy, and its flexibility allows the economic subject to change its behavior depending on the prevailing market environment. Prices have information and regulatory functions, which ensures the rational use of limited resources by market participants. The social market economy policy adapted in Germany is aimed at stabilizing the monetary system and using it such way, which will allow making the price the most representational for the analysis of supply and demand. In the conditions of "decentralized" local knowledge, the price is the most adjustable to the change in demand [4]. With the monopolistic price dictation, the coordinating mechanism is neutralized.

The preservation of competitive order and monopolization suppression are ensured by the private law system, which should ensure the observance of the competition rules and exclude the possibility of cartel agreements. The concept of private law society goes back to the works of F. Böhm, who sees the state's economic lever in its legislative power. In order to protect the consumer from economic power monopolization abuse, Böhm proposes to create a model charter dedicated to effective competition that would not allow monopolies to form [5]. At the same time, the tradition of solidarity when drafting contracts should be actively developed, since execution of contracts ensure further cooperation and building partnerships between economic entities. These ideas are reflected in the principle of the entrepreneur of the European Court.

The result of simultaneous effect of these rules is an increase in production and decrease in prices, which contributes to an increase in the welfare of a population.

\section{Ordoliberalism and the energy policy of Germany}

A special feature of the German gas market regulations is that they are based on the provisions of the Third Energy Package adopted by the European Union in 2009 (hereinafter referred to as TEP). TEP can be considered the basis of a competitive order establishment in the European gas market as a whole and in the German gas market particularly. TEP's main tasks are separation of suppliers and network operators, creation of independent national regulators, and development of transparent retail markets. These provisions are secured by two main EU regulations: No. 715 on conditions for access to the natural gas transmission networks and No. 73/2009 concerning common rules for the internal market in natural gas. The goal of these regulations is the reduction of prices for final consumers.

On the other hand, some experts highlight the low efficiency of the TEP, as well as the long implementation term that goes beyond the planned one. The arguments are the European Commission notifications on the implementation of TEP. In 2016,
Germany received a warning for not taking the measures required to apply the model of a separate network operator, and for not ensuring a satisfying independence of the state and the national energy regulator.

As the main model, German companies use an independent network operator model, which allows companies to retain the ownership of their transport infrastructure, but leave it under the strict control of regulatory bodies. This allows companies, cooperating with or operating in Germany, to use their capacity efficiently. This is especially important for companies using contractual pricing, whose interests lie in a constant utilization of transport capacities and projected consumption volumes. The largest supplier with about $40 \%$ of natural gas export share is the Russian company Gazprom, which has been traditionally forming the supply volume on the basis of contractual pricing.

According to researcher A. Konoplyanik, the Third Energy Package creates uncertainty for gas suppliers, therefore it may cause changes in future contracts conditions, for example, instead of $85 \%$ of "Take or pay" payments, Gazprom may request $100 \%$ to cover possible risks that may arise in case of pipelines turndown [6].

That is why the competition protection policy in industries with a high capital concentration and high capital investment is ineffective. A directive attempt to ensure the access of competitors to pipelines impedes the development of gas cooperation.

Recent trends show that the gas market monopolization level has not decreased significantly in 2017. For the calculation, we use the HerfindahlHirschman index, which shows the industry monopolization level [7].

$$
H H I=S_{1}^{2}+S_{2}^{2}+\mathrm{K}+S_{n}^{2}
$$

In the first formula, $S_{i}^{2}$ is the ratio of volume of sales of a particular exporter to total imports in the industry, and $\mathrm{n}$ is the number of importers in the industry

Currently, the geography of natural gas imports in Germany has not changed significantly since ten years ago. In 2017, Russia has supplied 36.5 billion cubic meters of natural gas, and its share in the supply amounted to $45 \%$ (Figure 1).

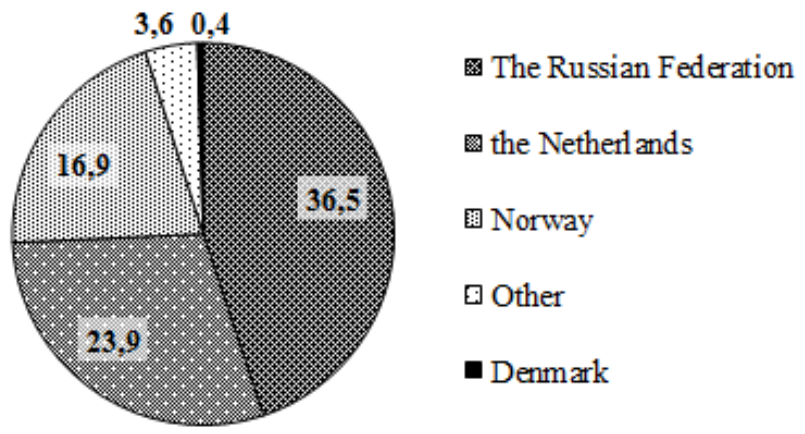

Fig. 1. Structure of natural gas import to Germany in 2017, in billion cubic meters (Source: McKinsey Energy Insights EU PipeFlow). 
When calculating the geographic concentration of natural gas imports in 2017, the HHI is 3,324, which indicates that the gas industry belongs to a highly concentrated market and is mainly represented by the Russian company Gazprom. It should be noted that in comparison with 2013, the HHI has only been increasing.

The second transformation feature is the change in the gas market pricing model. It is directly related to the institutional gas market transformation: the development of a hub system, where the pricing process will be carried out. Currently long-term contract prices flexibility is maintained by oil indexing with a 6-9 months lag, while gas-to-gas competition in virtual hubs will make the price more representational.

However, Germany can hardly boast a developed system of hub pricing. Thus, the German NCG hubs and Gaspool liquidity ratio was 5-10 in 2014-2015, while the British NBP and the Dutch TTF reached over 15 liquidity threshold, according to the EU Gas Target Model [8].

We can note that since 2014 the number of spot transactions has increased. In 2017, their share amounted to $42 \%$ of all transactions, which is $4 \%$ more in 2015 (Figure 2). Such changes force the suppliers to change their business models in Europe. Norway and the Netherlands have already switched to spot pricing. Russian Gazprom also has a number of proposals for spot trading on the German gas market. Therefore, there is a tendency to replace oil price indexing with intraindustry "gas-to-gas" competition.

At the same time, there is a contradiction resulting from the markets liberalization. Studies conducted by the National Energy Security Fund show that natural gas prices for enterprises have decreased, but at the same time the burden on retail consumers (householders) has increased significantly [9]. From 2008 to 2012, prices for final consumers have grown on a par by $40 \%$ across the EU. In the UK with its developed hubs system - by $53 \%$, in Germany - only by $13 \%$.

There is a correlation: the more the hub system is developed, the more the price of gas depends on market environment. The problem lies in the risks of unpredictable market fluctuation borne by both suppliers and consumers of gas. Such fluctuations contradict the ordoliberal concept and the idea of a social market economy, where the price stability is the ultimate goal, as well as a method leading to an increase in the welfare of a population.

Diversification of sources of power generation may be a way to control prices and maintain independence from external suppliers. The development of renewable energy sources (hereinafter referred to as RES) in Germany is the result of Energiewende 2.0 energy transformation program. According to the Fraunhofer Institute, the share of renewable energy in power generation reached $35.8 \%$, while the share of gas decreased to $8.4 \%$. In 2013 , the ratio was $27.6 \%$ and $14 \%$ correspondingly. In 2014-2018, the share of RES power increased by almost $11 \%$, replacing nuclear and traditional energy sources. At the same time, the installed capacity of RES continues to grow: in 2018, they amounted to 118.58 gigawatt (Figure 3).

Experts predicted a slowdown in the growth of RES capacity in Europe in 2016, associated with a decrease in investment returns. According to National Research University Higher School of Economics, investments in 2013 have decreased by more than two - to 57.3 billion dollars. Experts attribute such a decline to a lower number of state support and funding programs [10]. However, the production capacity has not decreased following the investment decline. In 2018, the installed capacity of electric generators increased by $15 \%$ compared with 2016. It may be related either to putting new stations in operation and achieving the effect or to an increase in the efficiency of stations.

Another area of economic policy is the creation of a competitive order by introducing additional players into the market. Such players may be American LNG suppliers.

At the same time, supplying LNG to Europe until 2014 was unprofitable for American companies because prices for the same products were higher in Asia. In 2015 , there has been a convergence of LNG prices in Europe and Asia, which made it economically expedient to redirect some of this energy source to Europe [11].

It is unprofitable for Germany to buy expensive American LNG; therefore, Gazprom is the preferable traditional supplier of gas to Europe. As for price competition, Gazprom may reduce prices in new contracts. This will make American LNG economically unprofitable for German buyers. All this forces the German government to be more flexible: to support the construction of Nord Stream 2 on the one hand, and to compromise with the USA on the other hand.

German Chancellor Angela Merkel announced that she supports the project to construct an LNG terminal in Germany. Such a step can be interpreted as concessions to the American LNG and stiffer competition in the gas market. It can be assumed that it was a political concession in relation with the Germany's desire to change the position of the USA in relation to Nord Stream 2.

At first glance, such intervention of state contradicts the natural course of market relations. According to the order management policy theory (Prozesspolitik) of the Freiburg school, the state should intervene to solve specific political issues that will preserve and improve the existing order policy. The German Chancellor's decision is to soften the USA policy of hard power. At the same time, maintaining gas industry cooperation with Russia remains the key task of the German energy policy.

\section{Adaptation of the Russian Federation to the restructuring of the gas market in Germany}

The possible scenarios that Gazprom should follow to further ensure its role in the German energy market are directly dependent on market environment factors, first of all, on the dynamics of natural gas price. With the 
competition from renewable energy sources and the American LNG, the price will play a decisive role in the economic expediency of gas projects $[12,13]$.

It was concluded in a study [14] that LNG remains uncompetitive in comparison with pipeline gas, and Asian prices are more attractive for suppliers rather than European. However, there was prices convergence in these regions by the end of 2017, gas prices increased, which made LNG supplies from the USA profitable. It is the impact of the technical and scientific progress and the shale gas revolution, resulting in the USA becoming a country influencing energy markets.

Gazprom is consequently forced, on the one hand, to make concessions, and on the other hand, to develop the current Nord Stream 2 project. The preventive measures that could be taken by the Russian company are associated with contract prices. One of the theoretical models that suits the situation is the Bertrand model.

This model is suitable for modeling situations in which both players, in order to force their competitor out of the market, start to reduce prices to marginal costs. The feature of the model is that producers do not cooperate with each other. The product is generally homogeneous and consumers are neutral to its characteristics, therefore they prefer cheaper product to more expensive one.

Producers can choose three possible strategies:

-Set a high price and lose the consumer.

-Set the same price as a competitor, and divide the market.

-Set a price lower than competitor's and capture the market.

With Bertrand competition model, players prefer to lower prices in order to monopolize the market. If companies maximize profits, they set the price at the level of marginal cost. Thus, they achieve this price equilibrium, which is established in a competitive market.

The described model can be mathematically formalized. In order to do so we construct a pricing model that considers the LNG pricing, pipeline gas contract prices and Asian LNG prices. In an article on the competitiveness of American LNG, the authors cite a pricing model that can be formalized as follows:

$$
\left\{\begin{array}{l}
P_{F O B}^{*} \geq P_{H H}^{\$}+C_{\text {liq }}^{\$} \\
P_{F R G}^{€} * E_{t}-C_{\text {ship/ger }}^{\$}-C_{r e g}^{€} * E_{t} \geq P_{F O B}^{*}
\end{array}\right.
$$

In the system of equations (1), $P_{F O B}^{*}$ is the FOB export price, which is greater than or equal to Henry Hub spot price plus liquation costs in dollars. The second equation of the system equates alternative supply directions $\left(P_{F R G}^{€} * E_{t}\right.$ ) to the dollar value, where $E_{t}$ - is the EUR/USD current month exchange rate. Transportation and deliquefying costs are deducted from it. However, this model does not reflect the formation of the contract price and the prices influence on the Asian market.
Suppose that American LNG producers focus only on economic benefits when choosing a market. Then the statement that the expenses in the European market should be lower than in the Asian one will be fair:

$$
\begin{aligned}
& P_{F O B}^{*}+C_{r e g}^{€} * E_{t}+C_{\text {ship } / g e r}^{\$} \leq \\
& \leq P_{F O B}^{*}+C_{r e g}^{\text {asian }} * R_{t}+C_{\text {ship/asian }}^{\$}
\end{aligned}
$$

In the equation $2,\left(C_{\text {reg }}^{\text {asian }} * R_{t}\right)$ is the cost of deliquefying in Asia, adjusted for the rate of the Asian currency to the dollar, and ( $C_{\text {ship/asian }}^{\$}$ ) is the cost of transportation to the Asian market.

Let us display the condition as follows:

$$
C_{\text {reg }}^{€} * E_{t}+C_{\text {ship/ger }}^{\$}-C_{\text {reg }}^{\text {asian }} * R_{t}-C_{\text {ship/asian }}^{\$} \leq 0
$$

At the same time, gas sales spot prices on the European market must be higher or equal to those of Asia, which makes the sale of one LNG power unit more profitable in Germany rather than on an alternative market.

Finally, one must remember the peculiarities of the contractual pricing, which implies the contract prices indexing depending on the price of Brent crude oil.

Overall, it will look as follows:

$$
P_{F R G}^{€} * E_{t}=k^{*} d P_{i}^{o i l}+P_{\text {contract }}^{\$}
$$

The equation 4 shows the indexing mechanism, where $\left(k^{*} d P_{i}^{\text {oil }}\right)$ is the mark-up at the moment the price of Brent crude oil changes in the i-period.

Overall, the model will look as follows:

$$
\begin{aligned}
& k^{*} d P_{i}^{\text {oil }}+P_{\text {contract }}^{\$}-C_{\text {reg }}^{€} * E_{t}-C_{\text {ship/ger }}^{\$}+ \\
& C_{\text {reg }}^{\text {asian } *} R_{t}+C_{\text {ship/asian }}^{\$} \geq P_{F O B}^{*}
\end{aligned}
$$

On the basis of presented model, we can derive the two following conditions under which LNG export is profitable for the USA:

If the pipeline gas contracts price is higher than the amount of LNG export expenses.

If the LNG power unit revenue in the Asian market is lower than in the European one (which is achieved by lowering the stock exchange prices on the Asian gas market or by increasing the expenses in the Asian market compared to the European one).

The current situation on the German gas market is only partially described by the Bertrand competition model, since the presuppositions for par and stability of marginal costs are not fulfilled. The company whose investment and production are the most profitable is the winner. The worldwide natural gas prices dynamics observed in 2017-2018 should last long enough, and American LNG production enterprises should reduce costs by introducing innovations in order to "win" the price war [15]. 
According to BAFA, the border gas prices are lower than hub prices. If the contractual pricing and high oil prices remain, consumer's benefits might become a contract price regulation tool. If the oil prices are reduced, the oil indexing leads to decrease in gas supplies prices, which ultimately may "crowd out" American LNG [16].

The second opportunity is product diversification. Russia, developing LNG projects, represented by Yamal LNG and Arctic LNG, may replace American gas.

\section{Conclusion}

Most of the economic and political decisions are based on ordoliberalism principles. At the same time, German gas market reforms, which are presented as liberal, do not correspond to the requirements and results that were formulated by theorists of the Freiburg school. The attempt of directive liberalization in the absence of developed institutions (in this case, gas hubs and stocks) lead to a disproportion. In an unfavorable scenario, the opposite results and rising prices are observed. The deceleration of the implementation of the German Third Energy Package confirms the attempts of the government to neutralize the negative consequences of the market architecture transformation.

Changes in pricing model create additional risks for suppliers and consumers, which forces them to adapt to new conditions. It is obvious that these changes should have been commenced with institutional changes accepted by all market participants. All these reforms are aimed at ensuring the contractual right.

The regulative role of the state in gas sector is not limited to legislative regulation of domestic and foreign markets. The state should ensure political and economic agility, which will create favorable conditions for the functioning of economic entities. It is assumed that under the framework conditions agents must choose the most effective strategies. In the conditions of competitive order Gazprom may take preventive steps by reducing contract prices and increasing gas offer; thus cooperation with Gazprom may be preferable for Germany.

Thus, the modern German energy policy in the gas market only partially corresponds to ordoliberalism principles. The theory of a coordinated market economy remains the core in making decisions.

\section{References}

[1] D. Lane, M. Myant, Varieties of Capitalism in Post-Communist Countries (Studies in Economic Transition) (Palgrave Macmillan, 278, 2007).

[2] F. Böhm, W. Eucken, H. Großmann-Doerth, Unsere Aufgabe: Ordnung der Wirtschaft (Heft 1: Die Ordnung der Wirtschaft als geschichtliche Aufgabe und rechtsschöpferische Leistung, Stuttgart and Berlin: W. Kohlhammer, 1935).

[3] W. Eucken, Grundsätze der Wirtschaftspolitik (Hrsg. von Edith Eucken and K. Pail Hensel, 6 durchges, Aufl. mit einem Vorwort zur
Neuausgabe 1990 von Ernst-Joachim Mestmäcker, 1952).

[4] I. Karen, Die Soziale Marktwirtschaft, (Alles, was Sie uber den Neoliberalismus wissen sollten, 2 Auflage, Frankfurt am Mai: Frankfurter Allgemeine Buch, 2014).

[5] M. Johim, Sicherung der Vertragsfreiheit durch Wettbewerbs- und Regulierungsrecht (Tubingen, 2015).

[6] A. Konoplyanik, Risks reduction and uncertainty of the Third Energy Package of the EU, Oil and gas vertical, 7, 79-88 (2012).

[7] D. Hulshof, J-P. van der Maat, M. Mulder, Market fundamentals, competition and naturalgas prices, Energy Policy, 94, 480-491 (2016). DOI: 10.1016/j.enpol.2015.12.016.

[8] P. Heather, The Evolution of European Traded Gas Hubs, Oxford Institute for Energy Studies (2016).

[9] K. Gugler, S. Heim, M. Janssen, M. Liebensteiner, Market Liberalization: Price Dispersion, Price Discrimination and Consumer Search in the German Electricity Markets, ZEW Centre for European Economic Research Discussion Paper, 18-042 (2018). DOI: 10.2139/ssrn.3267839.

[10] European Union 2016, Reference book on renewable power industry of the European Union: state-of-the-art review (Institute of power, 96, 2016).

[11] A. Oglend, P. Osmundsen, T. Selland, Kleppe Inversible Time Commitments for LNG Trade: Constraints on Spatial Market Integration IAEE International Conference. ISSN: 1559-792X.

[12] E. Orlova, New architecture of the gas market of the EU: the long-term contracts vs spot Oil\&Gas Journal Russia, 16-21 (2015).

[13] S. Pfoser, O. Schauer, Y. Costa, Acceptance of LNG as an alternarive fuel: Determinants and policy implication Energy Policy, 120, 259-267 (2018).

[14] E. Orlova, The American LNG in Europe: influence of a shale gas revolution of the USA on the markets of the EU gas Oil\&Gas Journal Russia, 22-25 (2017).

[15] S. Jonathan, The New Security Environment for European Gas: Worsening Geopolitics and Increasing Global Competition for LNG, Oxford Institute for Energy Studies (2006).

[16] F. Feijoo, I. Gokul, A. Charalampos, The future of natural gas infrastructure development in the United States, Applied Energy, 228, 149-166 (2018). DOI: 10.1016/j.apenergy.2018.06.037. 